\title{
Inkonsistensi Pengaturan Pertanggungjawaban Pidana Korporasi
}

\author{
Muhamad Soni Wijaya,Masruchin Ruba'I, Imam Koeswahyono \\ Fakultas Hukum Universitas Brawijaya \\ Soniw7y@gmail.com
}

\begin{abstract}
Most of the people still do not understand the existence of criminal acts by the corporation. This is due to the characteristics of this corporate crime is very complex. It can be understood because in the Criminal Code as the main body of material criminal law does not regulate the corporation as the subject of criminal law in Indonesia, corporate position as the subject of criminal law is currently only recently recognized in the Law regulating offenses outside the Criminal Code. This is because the Indonesian Criminal Code still adheres to a non-potest societas delinquere view which has not yet accommodated the corporate position as a subject of criminal law. The process of modernization and economic development, shows that corporations play an important role in people's lives. However, not infrequently the corporation in achieving its objectives, perform activities that deviate or contrary to the criminal law with the modus operandi performed. Therefore, the status of the corporation as the subject of law (Private law) has shifted into a crime, beside of criminal acts by human. This means that the doctrine of non-potest societas delinquere begins to be abandoned.
\end{abstract}

\section{Keywords : Liability, Corporation, Criminal law}

\begin{abstract}
Abstrak
Sebagian besar masyarakat masih kurang memahami adanya tindak pidana yang dilakukan oleh korporasi. Hal ini disebabkan karakteristik tindak pidana korporasi ini adalah sangat kompleks. Hal tersebut dapat dipahami karena dalam KUHP sebagai induk hukum pidana materiil tidak mengatur korporasi sebagai subyek hukum pidana di Indonesia kedudukan korporasi sebagai subjek hukum pidana saat ini secara khusus baru diakui dalam Undang-undang yang mengatur tindak pidana di luar KUHP. Hal ini dikarenakan Kitab Undang-undang Hukum Pidana Indonesia masih menganut pandangan societas delinquere non potest sehingga belum mengakomodir kedudukan korporasi sebagai subjek hukum pidana. Proses modernisasi dan pembangunan ekonomi, menunjukkan bahwa korporasi memegang peranan penting dalam kehidupan masyarakat. Namun demikian, tidak jarang korporasi dalam mencapai tujuannya, melakukan aktivitasaktivitas yang menyimpang atau yang bertentangan dengan hukum pidana dengan modus operandi yang dilakukan. Oleh karena itu, kedudukan korporasi sebagai subyek hukum (keperdataan) telah bergeser menjadi tindak pidana, disamping tindak pidana manusia alamiah (natuurlijk persoon). Hal ini berarti bahwa doktrin societas delinquere non potest mulai ditinggalkan.
\end{abstract}

\section{Kata Kunci : Tanggungjawab, Korporasi, Hukum Pidana}




\section{Pendahuluan}

Korporasi merupakan istilah yang biasa digunakan oleh para ahli hukum pidana dan kriminologi untuk menyebut apa yang dalam bidang hukum lain, khususnya bidang hukum perdata sebagai badan hukum, atau dalam bahasa Belanda disebut rechtpersoon atau dalam bahasa Inggris dengan istilah legal person atau legal body. Pengertian subjek hukum pada pokoknya adalah manusia dan segala sesuatu yang berdasarkan tuntutan kebutuhan masyarakat, yang oleh hukum diakui sebagai pendukung hak dan kewajiban. Pengertian yang kedua inilah yang dinamakan badan hukum.Menurut terminologi Hukum Pidana, bahwa 'korporasi adalah badan atau usaha yang mempunyai identitas sendiri, kekayaan sendiri terpisah dari kekayaan anggota.

Korporasi pada saat ini memiliki peranan yang sangat penting terhadap pertumbuhan ekonomi suatu negara, seperti meningkatkan penerimaan pajak dan standar hidup masyarakat, menciptakan lapangan pekerjaan, serta berkontribusi positif terhadap pertumbuhan suatu negara. Bahkan, dalam beberapa aspek peranan korporasi melebihi peranan dan pengaruh suatu negara. Namun demikian, peranan penting dan positif korporasi terhadap pertumbuhan ekonomi suatu negara seringkali diikuti oleh pelanggaranpelanggaran yang mengarah pada hukum pidana. Tidak jarang korporasi melakukan unfair business yang tidak hanya merugikan suatu negara dan konsumen, tapi juga dapat dikategorikan sebagai tindak pidana. Ketika korporasi melakukan tindak pidana, maka ia dapat dipertanggungjawabkan atas tindak pidana yang dilakukan baik ditujuukan kepada pengurusnya maupun ditujukan langsung kepada korporasi.

Pengakuan korporasi sebagai subjek dalam hukum pidana bukan merupakan hal baru dan tidak menimbulkan persoalan hukum yang berarti. Dalam KUHP sebagai induk hukum pidana materiil tidak mengatur korporasi sebagai subyek hukum pidana di Indonesia kedudukan korporasi sebagai subjek hukum pidana saat ini secara khusus baru diakui dalam Undang-Undang 
yang mengatur tindak pidana di luar KUHP. Hal ini dikarenakan Kitab Undang-undang Hukum Pidana Indonesia masih menganut pandangan societasdelinquere non potest (Hutauruk, 2013:21-22) dengan angapan bahwa :

a) Korporasi tidak mempunyai mens rea (keinginan berbuat jahat).

b) Korporasi bukan seorang pribadi meskipun korporasi dapat melakukan berbagai perbuatan hukum yang biasanya dilakukan oleh orang pribadi.

c) Korporasi tidak memiliki kesadaran dan tidak punya badan actual (no soul to be damned and no body kicked)

d) Korporasi tidak dapat dimintai pertanggungjawaban karena jika ada kejahatan yang dilakukan oleh direksi suatu korporasi, hal tersebut sudah pasti merupakan perbuatan di luar anggaran dasar dari korporasi yang bersangkutan, sehingga dalam hal seperti itu maka yang bertanggungjawab adalah direksinya secara pribadi atau secara bersama-sama dengan direksi lain, tetapi bukankorporasi yang harus bertanggungjawab (doktrin ultra vires).

Sehingga belum mengakomodir kedudukan korporasi sebagai subjek hukum pidana. Untuk mencegah semakin luasnya kejahatan korporasi maka sistim hukum nasional sejak tahun 1951 telah memperkenalkan korporasi sebagai subyek tindak pidana (Pasal 11 ayat (1) UU No. 17/Drt/1951). Tidak sampai disitu saja, pada tahun 1955 kembali ditegaskan posisi korporasi sebagai subyek tindak pidana dalam tindak pidana ekonomi sehingga dapat dimintai pertanggungjawaban pidana (Pasal 39 ayat (2) UU No. 7/Drt/1955).

Diaturnya dalam undangundang yang mengatur korporasi dapat dimintakan pertanggungjawaban pidana tersebut ikut menstimulasi perundang-undangan lain yang juga memposisikan korporasi sebagai subyek delik antara lain Undangundang Nomor 20 Tahun 2001 tentang Pemberantasan Tindak Pidana Korupsi ${ }^{1}$ (selanjutnya UU 
TIPIKOR), dan Undang-undang Nomor 32 Tahun 2009 tentang Pengelolaan dan Perlindungan Lingkungan Hidup (selanjutnya UU PLKH).

Jika melihat rumusan norma pada kedua undang-undang tersebut, maka dapat diketahui bahwa ada pengaturan yang berbeda antara undang-undang yang satu dengan undang-undang yang lain perihal korporasi sebagai subyek tindak pidana, dalam pasal 20 ayat (1) Undang-undang TIPIKOR menyebutkan bahwa dalam hal tindak pidana korupsi dilakukan oleh atau atas nama suatu korporasi, maka tuntutan dan penjatuhan pidana dapat dilakukan terhadap korporasi dan atau pengurusnya. Pengaturan yang berbeda dapat dilihat dalam undangundang PLKH Pasal 116 ayat (1) memiliki karakter sendiri dalam merumuskan pertanggungjawaban pidana korporasi. Apabila tindak pidana lingkungan hidup dilakukan oleh atas nama badan usaha, tuntutan pidana dijatuhkan kepada badan usaha dan/atau orang yang memberikan perintah untuk melakukan tindak pidana tersebut. Tegasnya dari ketiga undang-undang diatas masing-masing memiliki rumusan yang berbeda dalam mengatur korporasi sebagai subyek tindak pidana.

Jadi jika memperhatikan rumusan undang-undang tersebut diatas, maka dapat diketahui bahwa antara undang-undang tidak memiliki konsep yang sama dalam menempatkan korporasi sebagai subyek tindak pidana ada ketidakkonsistenan atau inkonsistensi. Hal ini akan berimbas dalam penerapanya oleh aparat penegak hukum, sebab dapat menimbulkan ketidak pastian hukum. Penelitian ini bertujuan untuk mengetahui, memahami dan menganalisis bentuk inkonsistensi pengaturan pidana korporasi pada perudang undangan di Indonesia

\section{Metode Penelitian}

Penelitian ini merupakan penelitian hukum (legal research), yang merupakan serangkaian tindakan atau proses untuk menemukan hukum disebabkan terjadinya kekosongan hukum (vacuum norm), kekaburan norm (obscuur norm) maupun konflik norm (conflict of norm) atau 
menemukan asas hukum, yang mengatur norma hukum yang mengikat secara umum dan dibentuk atau ditetapkan oleh lembaga atau pejabat yang berwenang melalui prosedur yang ditetapkan dalam peraturan perundang-undangan, khususnya yang berkenaan dengan norma yang mengatur kebijakan hukum pidana di bidang perikanan dalam kedaulatan negara

\section{Pembahasan}

Secara umum, hukum tidak hanya mengatur orang (manusia alamiah) sebagai subjek hukum, akan tetapi selain orang perseorangan dikenal pula subjek hukum yang lain yaitu badan hukum (korporasi) yang padanya melekat hak dan kewajiban hukum layaknya orang perseorangan sebagai subjek hukum. Atas dasar itu, untuk mencari tahu apa yang dimaksud dengan korporasi, tidak bisa dilepaskan dari bidang hukum perdata. Hal ini disebabkan oleh karena istilah korporasi sangat erat kaitannya dengan istilah "badan hukum" yang dikenal dalam bidang hukum perdata.

Perlu pula dikemukakan bahwa menurut Rudi Prasetya, Kata korporasi adalah sebutan yang lazim dipergunakan di kalangan pakar hukum pidana untuk menyebut apa yang biasa dalam bidang hukum lain, khususnya bidang hukum perdata, sebagai badan hukum, atau yang dalam bahasa Belanda disebut sebagai rechts persoon, atau yang dalam bahasa Inggris disebut legal entities atau corporation (Muladi dan Dwija, 1991:13).

Secara etimologisnya, pengertian korporasi yang dalam istilah lain dikenal dengan corporatie (Belanda), corporation (Inggris), korporation (Jerman), berasal dari bahasa Latin yaitu "corporatio" (Muladi dan Dwija, 1991:13).

Terkait dengan istilah "corporatio" ini, menurut Muladi dan Dwidja Priyatno:

Seperti halnya dengan kata lain yang berakhiran dengan "tio" maka "corporatio" dianggap sebagai kata benda (substantivum) yang berasal dari kata kerja "corporare" yang banyak dipakai orang pada zaman abad pertengahan atau sesudah itu. "Corporare" itu sendiri berasal dari kata "corpus" yang dalam bahasa Indonesia berarti "badan" atau dapat disimpulkan bahwa corporatio dapat diartikan sebagai proses memberikan badan atau proses membadankan. Dengan demikian, maka akhirnya "corporatio" itu berarti hasil pekerjaan membadankan, dengan perkataan 
lain, korporasi merupakan badan yang dijadikan orang, badan yang diperoleh dengan perbuatan manusia sebagai lawan terhadap badan manusia, yang terjadi menurut alam (Muladi dan Dwija, 1991:12).

\section{Menurut Satjipto Rahardjo} bahwa :

Badan yang diciptakannya itu terdiri dari corpus, yaitu struktur fisiknya dan ke dalamnya hukum memasukkan unsur animus yang membuat badan itu mempunyai kepribadian. Oleh karena badan hukum ini merupakan ciptaan hukum, maka kecuali penciptaannya, kematiannya pun ditentukan oleh hukum (Satjipto,2000:13).

Secara luas sebagai pengertian korporasi dalam hukum pidana, Sutan Remi Sjahdeini mendefinisikan korporasi sebagai berikut:

Dalam hukum pidana, korporasi meliputi baik badan hukum maupun bukan badan hukum. Bukan saja badan-badan hukum seperti perseroan terbatas, yayasan, koperasi atau perkumpulan yang telah disahkan sebagai badan hukum yang digolongkan sebagai korporasi menurut hukum pidana, tetapi juga firma, persekutuan komanditer atau $C V$, dan persekutuan atau maatschap, yaitu badan-badan usaha yang menurut hukum perdata bukan suatu badan hukum" (Sjahdeini, 2006:45).

Dari pendapat di atas terlihat bahwa ada perbedaan ruang lingkup mengenai subjek hukum, yaitu korporasi sebagai subjek hukum dalam bidang hukum perdata dengan korporasi sebagai subjek hukum dalam bidang hukum pidana. Pengertian korporasi dalam bidang hukum perdata adalah "badan hukum", sedangkan dalam hukum pidana pengertian korporasi bukan hanya yang berbadan hukum, tetapi juga yang tidak berbadan hukum. Meskipun demikian, perlu disadari bahwa beberapa pengertian korporasi sebagaimana dikemukakan diatas merupakan pengertian korporasi yang disampaikan oleh para ahli hukum sedangkan perumusan definisi sebagai hukum positif belum ada. Keadaan ini tentu dalam prakteknya akan menimbulkan ketidakpastian hukum karena penafsiran apa yang dimaksud dengan "korporasi" akan sangat bergantung dari pendapat siapa kita berangkat. Singkatnya, apabila dilihat dari sudut pandang hukum pidana Indonesia, terminologi "korporasi" belum didefinisikan secara tegas. Hal ini merupakan hal yang wajar mengingat dalam hukum pidana Indonesia yang merupakan 
peninggalan Belanda masing ruang lingkupnya diatur sedemikian menganut individual responsibility.

Berikut ini akan diuraikan luas (lebih luas dari pengertian korporasi dalam hukum perdata) Pengaturan korporasi sebagai subjek yaitu sebagaimana diatur dalam tindak pidana yang terdapat dalam Undang-undang berikut ini:

berbagai peraturan perundangundangan khusus diluar KUHP yang

Tabel 1.

Perumusan/penyebutan korporasi sebagai subyek hukum, aturan pemidanaan korporasi dan model pertanggungjawaban korporasi dalam Undang-Undang TIPIKOR dan Undang-Undang PLKH

\begin{tabular}{|c|c|c|c|c|c|}
\hline No & $\begin{array}{l}\text { Undang- } \\
\text { Undang }\end{array}$ & $\begin{array}{c}\text { Penyebutan subyek } \\
\text { "Korporasi" }\end{array}$ & & $\begin{array}{l}\text { Iran pemidanaan } \\
\text { korporasi }\end{array}$ & $\begin{array}{c}\text { Model } \\
\text { pertanggungjawaban }\end{array}$ \\
\hline 1 & $\begin{array}{l}\text { UU Tindak } \\
\text { Pidana Korupsi } \\
\text { UU No } 31 \text { Th } \\
1999\end{array}$ & $\begin{array}{l}\text { Dalam bab yang } \\
\text { mengatur tindak pidana } \\
\text { digunakan istilah : } \\
\text { dalam hal dilakukan } \\
\text { oleh atau atas nama } \\
\text { korporasi } \\
\text { Pengertian korporasi } \\
\text { dijelaskan dalam Pasal } \\
1 \text { ke } 1 \text { korporasi adalah } \\
\text { kumpulan orang dan } \\
\text { atau kekayaan yang } \\
\text { terorganisir baik } \\
\text { merupakan badan } \\
\text { hukum mapun bukan } \\
\text { badan hukum. }\end{array}$ & $\begin{array}{r}\square \quad \mathrm{P} \\
(1) \\
\end{array}$ & 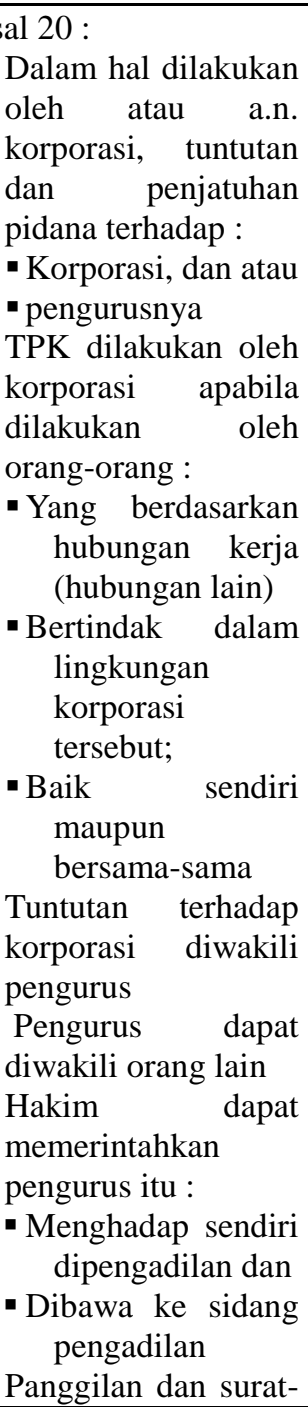 & $\begin{array}{l}\text { Adapun model } \\
\text { pertanggungjawaban } \\
\text { pidana dalam Undang- } \\
\text { Undang ini } \\
\text { Pengurus Korporasi } \\
\text { Sebagai Pembuat Dan } \\
\text { juga yang } \\
\text { Bertanggungjawab . } \\
\text { Hal ini diatur didalam } \\
\text { pasal } 20 \text { Dalam hal } \\
\text { tindak pidana korupsi } \\
\text { dilakukan oleh atas } \\
\text { nama suatu korporasi, } \\
\text { maka tuntutn dan } \\
\text { penjatuhan pidana dapat } \\
\text { dilakukan terhadap } \\
\text { korporasi dan atau } \\
\text { pengurusnya }\end{array}$ \\
\hline
\end{tabular}




\begin{tabular}{|c|c|c|c|c|}
\hline & & (7) & $\begin{array}{l}\text { surat disampaikan ke } \\
\text { tenpat tinggal } \\
\text { pengurus atau ke } \\
\text { kantornya } \\
\text { Pidana pokok hanya } \\
\text { denda dengan } \\
\text { maksimum ditambah } \\
1 / 3\end{array}$ & \\
\hline $\begin{array}{l}\text { UU Lingkungan } \\
\text { Hidup } \\
\text { UU No. } 23 \text { Th } \\
1997 \text { yang } \\
\text { digantikan oleh } \\
\text { UU No. } 32 \text { Th } \\
1999\end{array}$ & $\begin{array}{l}\text { UU 23/1997: } \\
\text { Jika dilakukan oleh } \\
\text { atau a.n. suatu } \\
\text { badan hukum, } \\
\text { perseroan, } \\
\text { perserikatan, } \\
\text { yayasan, atau } \\
\text { organisasi lain } \\
\text { (Pasal 46 (1)) } \\
\text { UU 32/1999 } \\
\text { - Istilah korporasi } \\
\text { hanya disebut } \\
\text { dalam penjelasan } \\
\text { umum } \\
\text { Dalam bab } \\
\text { ketentuan pidana } \\
\text { digunakan istilah } \\
\text { badan usaha (Pasal } \\
\text { 116 dan 119): } \\
\text { apabila tindak } \\
\text { pidana lingkungan } \\
\text { hidup dilakukan } \\
\text { oleh, untuk, atau } \\
\text { atas nama badan } \\
\text { usaha) } \\
\text { Dalam ketentuan } \\
\text { Umum Pasal } 1 \text { sub } 32 \text { : } \\
\text { setiap orang } \\
\text { adalahperseorangan } \\
\text { atau badan usaha, baik } \\
\text { yang berbadan hukum } \\
\text { maupun yang tidak } \\
\text { berbadan hukum }\end{array}$ & \multicolumn{2}{|c|}{ 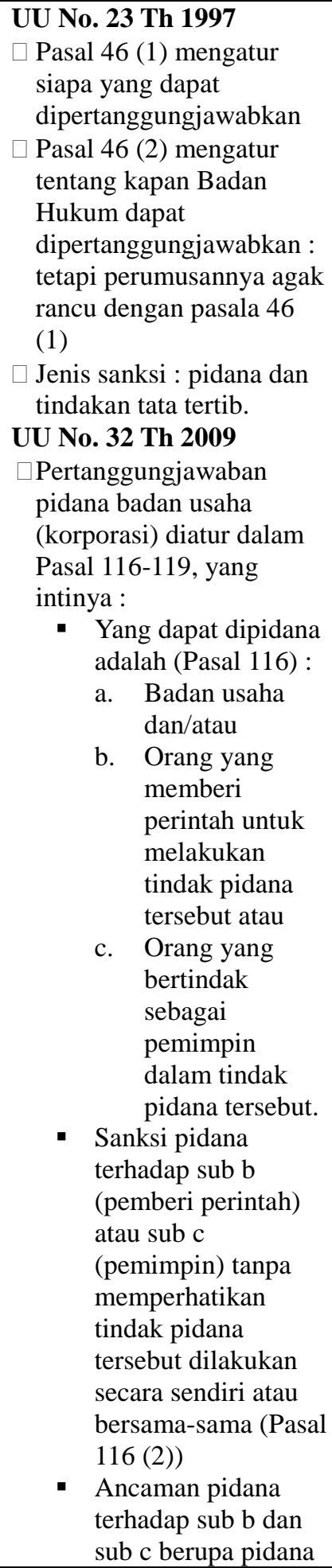 } & $\begin{array}{l}\text { Adapun model } \\
\text { pertanggungjawaban } \\
\text { pidana dalam Undang- } \\
\text { Undang ini terdiri dari } \\
\text { dua model. } \\
\text { Model pertama } \\
\text { adalah Korporasi } \\
\text { Sebagai Pembuat } \\
\text { Dan } \\
\text { Bertanggungjawab. } \\
\text { Hal ini diatur dalam } \\
\text { Pasal 116 ayat (1) } \\
\text { :apabila tindak } \\
\text { pidana lingkungan } \\
\text { hidup dilakukan } \\
\text { oleh, untuk, atau atas } \\
\text { nama badan usaha, } \\
\text { tuntutan pidana dan } \\
\text { sanksi pidana } \\
\text { dijatuhkan kepada: } \\
\text { a. badan usaha, } \\
\text { dan/atau b. orang } \\
\text { yang memberi } \\
\text { perintah untuk } \\
\text { melakukan tindak } \\
\text { pidana tersebut atau } \\
\text { orang yang } \\
\text { melakukan tindak } \\
\text { pidana sebagai } \\
\text { pemimpin kegiatan } \\
\text { dalam tindak pidana } \\
\text { tersebut. } \\
\text { Catatan : bahwa } \\
\text { tuntutan pidana dan } \\
\text { sanksi pidana dapat } \\
\text { dijatuhkan salah } \\
\text { satunya kepada } \\
\text { "Badan Usaha" } \\
\text { Model kedua adalah } \\
\text { Korporasi Sebagai } \\
\text { Pembuat Dan } \\
\text { Pengurus } \\
\text { Bertanggungjawab. } \\
\text { Hal ini diatur dalam } \\
\text { yanal } 116 \text { ayat (1), } \\
\text { bahwa } \\
\text { pertanggungjawaban } \\
\text { pidana dapat }\end{array}$ \\
\hline
\end{tabular}




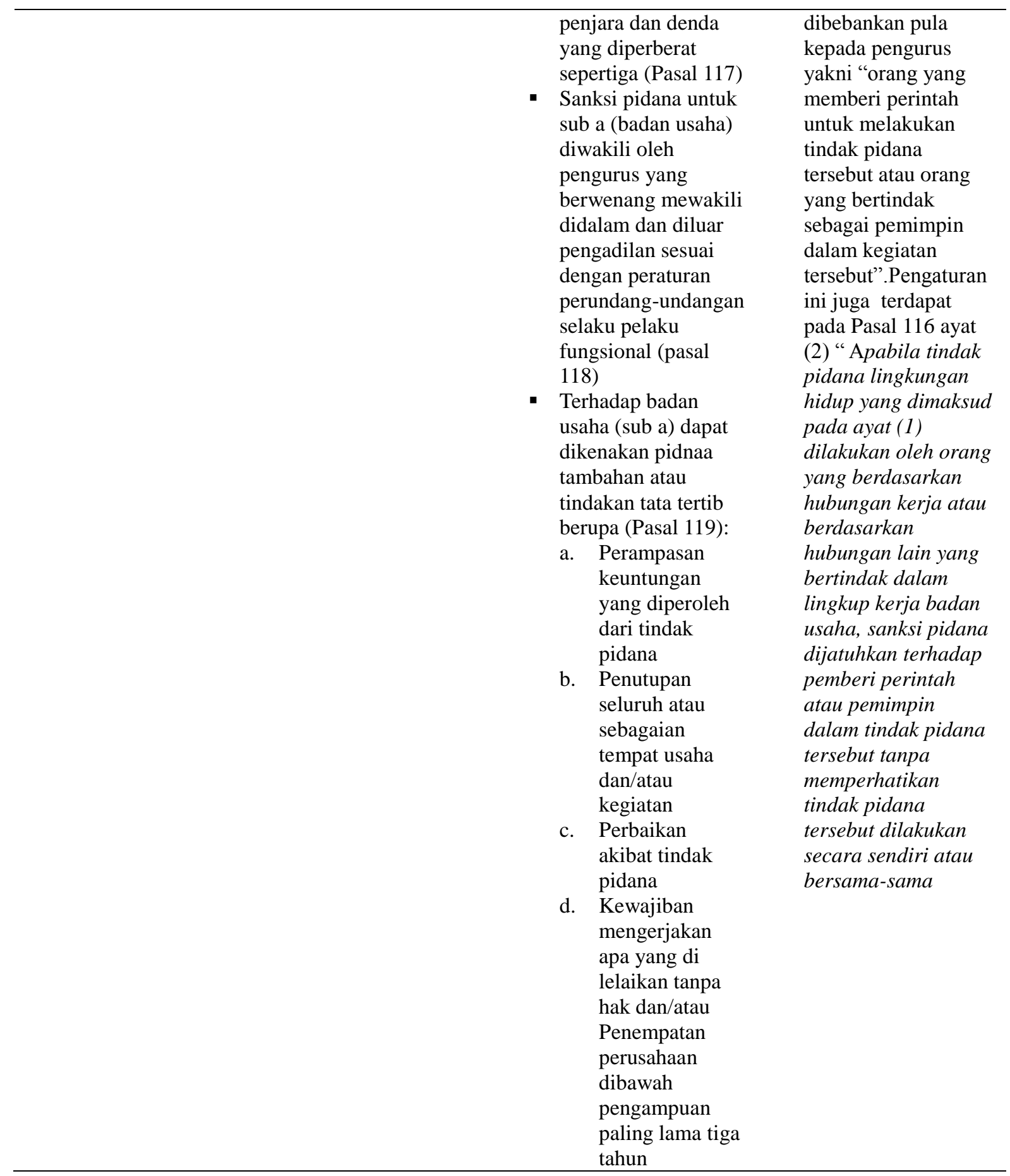

Sumber : Bahan Hukum Primer diolah

Dari tabel 1baik mengenai perumusan penyebutan korporasi sebagai subyek tindak pidana aturan pemidanaan korporasi dan model/sistim pertanggungjawaban pidana terhadap tiga undang-undang dapat disimpulkan halhal sebagai berikut :

Tabel 2 
Perbandingan pengaturan

\begin{tabular}{|c|c|c|c|}
\hline No & PENGATURAN & $\begin{array}{c}\text { UU } \\
\text { TIPIKOR }\end{array}$ & $\begin{array}{c}\text { UU PPLH/ } \\
\text { LINGKUNGAN }\end{array}$ \\
\hline 1 & $\begin{array}{l}\text { Korporasi sebagai subyek } \\
\text { tindak pidana }\end{array}$ & $\begin{array}{l}\text { Pasal } 1 \text { angka (3) } \\
\text { menjelaskan bahwa } \\
\text { korporasi merupakan subjek } \\
\text { hukum yang dapat dimintai } \\
\text { pertanggungjawaban pidana }\end{array}$ & $\begin{array}{l}\text { Pasal } 1 \text { angka } 32 \\
\text { menjelaskan bahwa badan } \\
\text { hukum termasuk subjek } \\
\text { tindak pidana }\end{array}$ \\
\hline 2 & $\begin{array}{l}\text { Pertanggung jawaban } \\
\text { pengurus }\end{array}$ & $\begin{array}{l}\text { Pasal } 20 \text { ayat (1) tidak } \\
\text { menyebutkan mengenai } \\
\text { siapa saja pengurus yang } \\
\text { bertanggungjawab }\end{array}$ & $\begin{array}{l}\text { Pasal } 116 \text { ayat }(2), \text { yang } \\
\text { termasuk pengurus antara } \\
\text { lain:orang yang memberi } \\
\text { perintah atau pemimpin }\end{array}$ \\
\hline 3 & $\begin{array}{l}\text { Pola/model perumusan } \\
\text { pertanggungjawaban } \\
\text { pidana korporasi }\end{array}$ & $\begin{array}{l}\text { Pasal } 20 \text { ayat (1), pola } \\
\text { perumusan } \\
\text { pertanggungjawaban } \\
\text { bersifat alternatif-kumulatif } \\
\text { karena adanya kata hubung } \\
\text { "dan/atau" }\end{array}$ & $\begin{array}{l}\text { Pasal } 116 \text { ayat (1), pola } \\
\text { perumusan } \\
\text { pertanggungjawaban } \\
\text { bersifat alternatif-kumulatif } \\
\text { karena adanya kata hubung } \\
\text { "dan/atau" }\end{array}$ \\
\hline 4 & $\begin{array}{l}\text { Kriteria korporasi } \\
\text { melakukan tindak pidana }\end{array}$ & $\begin{array}{l}\text { Pasal } 20 \text { ayat (2), korporasi } \\
\text { melakukan tindak pidana } \\
\text { apabila dilakukan oleh } \\
\text { orang-orang yang } \\
\text { mempunyai hubungan kerja } \\
\text { atau hubungan lain dalam } \\
\text { lingkup pekerjaannya, baik } \\
\text { sendiri-sendiri maupun } \\
\text { bersama-sama }\end{array}$ & $\begin{array}{l}\text { Pasal } 116 \text { ayat (2), apabila } \\
\text { dilakukan oleh orang, yang } \\
\text { berdasarkan hubungan kerja } \\
\text { atau berdasarkan hubungan } \\
\text { lain yang bertindak dalam } \\
\text { lingkup kerja badan usaha }\end{array}$ \\
\hline 5 & $\begin{array}{l}\text { Pihak yang mewakili } \\
\text { apabila korporasi dituntut } \\
\text { secara pidana }\end{array}$ & $\begin{array}{l}\text { Pasal } 20 \text { ayat (3), apabila } \\
\text { korporasi dituntut secara } \\
\text { pidana maka yang mewakili } \\
\text { dipersidangan adalah } \\
\text { pengurus }\end{array}$ & $\begin{array}{l}\text { Pasal118, apabila korporasi } \\
\text { dituntut secara pidana maka } \\
\text { yang mewakili } \\
\text { dipersidangan adalah } \\
\text { pengurus }\end{array}$ \\
\hline
\end{tabular}

Sumber : Bahan Hukum Primer, diolah

Berdasarkan ketentuan dalam

berbagai Undang-undang tersebut

diatas, Barda Nawawi Arief

menyimpulkan bahwa (Barda,

2003:226):

1) Penentuan korporasi sebagai

subjek tindak pidana hanya

untuk tindak pidana tertentu,

yang diatur dalam undang-

undang khusus

2) Pada awalnya tidak digunakan istilah "korporasi", tetapi digunakan istilah yang

bermacam-macam

(tidak

seragam) dan tidak konsisten;

3) Istilah "korporasi" mulai terlihat

pada tahun 1997 dalam Undang-

Undang Psikotropika yang

dipengaruhi oleh istilah dalam

Konsep KUHP atau Rancangan

KUHP tahun 1993.

Dari berbagai peraturan di atas,

dapat dilihat bahwa pengaturan

korporasi sebagai subjek hukum 
pidana hanya terdapat dalam

kejelasan

terkait

undang-undang khusus diluar

pertanggungjawaban

pidana

KUHP. Oleh karena itu, perumusan

korporasi, hal ini dimungkinkan korporasi sebagai subjek hukum pidana sebaiknya diatur secara tegas dalam Buku I KUHP sehingga dapat diberlakukan bagi seluruh tindak pidana yang terjadi baik tindak pidana yang diatur dalam KUHP maupun tindak pidana yang diatur diluar KUHP.

Perbedaan pengaturan terkait pertanggungjawaban pidana bagi korporasi dalam system peraturan perundang-undangan di Indonesia terkhusus pengaturan undangundang yang telah dijelaskan pada table.1 diatas dapat mengakibatkan adanya ketidakpastian hukum dan disharmonisasi pengaturan yang dapat mengakibatkan terhambatnya penegakan hukum. Kemudian dalam hal ini perlu adanya rekonstruksi terkait pengaturan pertanggungjawaban pidana bagi korporasi demi terciptanya tujuan hukum yaitu keadilan, kepastian dan kemanfaatan.

Berdasarkan teori perundangundangan ini perlu adanya penyamaan makna atau persamaan peraturan untuk memberikan suatu untuk mencari kejelasan dan kejernihan makna atau pengertianpengertian, dan bersifat kognitif, demi terciptanya tujuan hukum yaitu keadilan, kepastian dan kemanfaatan.

\section{Simpulan}

Dengan diakomodirnya kedudukan korporasi sebagai subjek hukum pidana umum, sebagaimana yang terjadi dalam perubahan KUHP Belanda (W.v.S) tahun 1976, menjadikan korporasi dapat dianggap sebagai pelaku tindak pidana seperti manusia sebagai subjek hukum. Berbeda dengan sebelumnya, dimana kedudukan korporasi sebagai subjek hukum pidana hanya diakomodir oleh Undang-undang di luar KUHP yang mengatur mengenai delik-delik tertentu.Pengaturan di luar KUHP tersebut menjadikan pengaturan terhadap korporasi sebagai subjek hukum pidana dan pertanggungjawaban pidanya berbeda antara satu peraturan dengan peraturan lainnya. Tentunya hal ini akan menimbulkan ketidakpastian 
mengenai pengaturan pidana seperti apa yang berlaku terhadap korporasi di Indonesia.

\section{Daftar Pustaka}

\section{Buku}

Muladi dan Dwidja Priyatno. (1991) Pertanggungjawaban

Korporasi dalam Hukum Pidana, Bandung: STHB

Rahardjo, Satjipto. (2000) Ilmu Hukum, Bandung: Citra Aditya Bakti

Sjahdeini, Sutan Remi. (2006) Pertanggungjawaban Pidana Korporasi, Jakarta: Grafiti Pers

Arief , Barda Nawawi. (2003) Kapita Selekta Hukum Pidana, Bandung:Citra Aditya Bakti

Hutauruk, Rufinus Hotmaulana. (2013) Penanggulangan Kejahatan Korporasi Melalui Pendekatan Restoratif Suatu Terobosan Hukum, Jakarta: Sinar Grafika

\section{Peraturan Perundang-undangan}

Republik Indonesia, Undang-undang Dasar Negara Republik Indonesia Tahun 1945

Republik Indonesia, Undang-undang No. 17 Tahun 1951 tentang Penimbunan Barang-barang

Republik Indonesia, Undang-undang No. 7 Tahun 1955 tentang Pengusutan, Penuntutan dan Peradilan Tindak Pidana Ekonomi
Republik Indonesia, Undang-undang No. 20 Tahun 2001 tentang Pemberantasan Tindak Pidana Korupsi

Republik Indonesia, Undang-undang No. 32 Tahun 2009 tentang Pemberantasan Tindak Perlindungan dan Pengelolaan Lingkungan Hidup

Republik Indonesia, Undang-undang No. 1 Tahun 1946 Kitab Undang-undang Hukum Pidana 